Секция 10. Фотонные кристаллы, микрорезонаторы и метаматериалы. Нанофотоника

\title{
Явления усиления излучающих свойств активной среды в фотонных кристаллах и фотонно-кристаллических резонаторах, сформированных на кремниевых структурах с наноостровками Ge(Si)
}

\author{
Степихова М.В. ${ }^{1}$, Яблонский А.Н. ${ }^{1}$, Дьяков С.А. ${ }^{2}$, Скороходов Е.В. ${ }^{1}$, Шалеев М.В. ${ }^{1}$,
} Сергеев С.М. ${ }^{1}$, Новиков А.В. ${ }^{1}$, Гиппиус Н.А. ${ }^{2}$, Красильник 3.Ф. ${ }^{1}$

${ }^{1}$ ИФМ РАН, 603950, Нижний Новгород, ГСП-105

${ }^{2}$ Сколковский институт науки и технологий, 143005, Москва, ул. Нобеля, 3

DOI 10.34077/Semicond2019-412

В работе рассмотрены люминесцентные свойства фотонных кристаллов (ФК) и фотоннокристаллических резонаторов, сформированных на кремниевых структурах с наноостровками $\mathrm{Ge}(\mathrm{Si})$. Интерес к таким структурам обусловлен, прежде всего, перспективами создания на их основе эффективных источников излучения для схем микроэлектроники с оптической обработкой сигнала. В данном случае встраивание активной среды в фотонные кристаллы и фотонно-кристаллические резонаторы предполагает поиск возможностей управления излучающими свойствами среды за счет эффектов взаимодействия с высокодобротными модами низкоразмерных резонаторов и фотонных кристаллов.

Исследованные в работе ФК и ФК-резонаторы формировались методами электронно-лучевой литографии и плазмохимического травления на многослойных структурах $\mathrm{SOI} / \mathrm{n}(\mathrm{Ge} \mathrm{QDs}-\mathrm{Si})$. Период решетки ФК (а) варьировался в широких пределах от 350 до 1000 нм, т.е. в диапазоне значений, сравнимых и значительно превышающих длину волны излучения в исследуемом материале. Радиус отверстий (r) определялся соотношением $\mathrm{r} / \mathrm{a}=0.2 \div 0.4$. Полученные структуры исследовались методом микро-фотолюминесценции с высоким пространственным (до 2 мкм) и спектральным (>0.05 см-1) разрешением.

Результаты проведенных исследований показывают, что, в зависимости от параметров ФК, в таких структурах возможно наблюдение явлений усиления сигнала ФЛ наноостровков $\mathrm{Ge}(\mathrm{Si})$ на высокодобротных модах ФК-резонатора и собственных модах ФК, где под собственными модами ФК подразумеваются моды, локализованные в Г точке зоны Бриллюэна [1]. Усиление сигнала ФЛ на модах ФК-резонатора наблюдалось в резонаторах с периодом решетки ФК, не превышающим 500 нм, и имело место при условии прецизионной фокусировки возбуждающего лазерного луча в области резонатора. В ФК и резонаторах с периодом решетки, превышающим 500 нм, усиление сигнала ФЛ не зависело от области возбуждения и связано с явлениями взаимодействия оптически активной среды с собственными модами ФК. В обоих случаях имело место значительное, более чем на порядок величины, усиление сигнала ФЛ наноостровков $\mathrm{Ge}(\mathrm{Si})$, причем в последнем случае наблюдался. в том числе, и значительный рост интегральной интенсивности сигнала.

Полученные в работе экспериментальные результаты хорошо описываются в рамках теоретических моделей, позволяющих проанализировать зонную структуру исследованных ФК и особенности модового состава ФК резонаторов. Моделирование исследуемых структур проводилось методами матрицы рассеяния и конечных элементов (FEM) с использованием программного пакета COMSOL Multiphysics.

Работа поддержана РФФИ (проект \#18-42-520047-р_а) и частично финансируется программой фундаментальных исследований Президиума РАН «Наноструктуры: физика, химия, биология, основы технологий».

[1] M.V. Stepikhova et al., Semicond. Sci. Techn. 34, 024003 (2019). 